\title{
Sustainable Development Goals and India's Commitment to Gender Justice
}

\author{
Dr. Anas Jameel ${ }^{1 *} \&$ Dr. Waseem Ahmed ${ }^{2}$ \\ ${ }^{1}$ Senior Research Fellow, Department of Political Science, Aligarh Muslim University, Aligarh, India \\ Orcid id: https://orcid.org/0000-0001-9956-1825 \\ ${ }^{2}$ Assistant Professor(Political Science), Glocal Law School, Glocal University, Saharanpur, UP, India \\ Orcid id: https://orcid.org/0000-0002-9547-2689 \\ ${ }^{*}$ Correspondence Email: anasjameelamu@gmail.com, \\ https://riiopenjournals.com/index.php/society sustainability/index
}

Doi:https:https//doi.org/10.38157/society_sustainability.v3i2.347

Citation: Jameel, A. \& Ahmed, W. (2021). Sustainable Development Goals and India's Commitment to Gender Justice, Society \& Sustainability, 3(2), 68-86. Doi: https://doi.org/10.38157/society_sustainability.v3i2.347

\section{Research Note}

\begin{abstract}
Abst ract
Sustainable Development Goals are a set of seventeen interconnected objectives to achieve a sustainable future for all. They take a holistic and multidimensional approach to development to alter our planet by addressing humanity's many difficulties. It is an essential component of all aspects of inclusive and longterm growth. Women need to have equal rights and opportunities and live without fear of prejudice or violence. Goal five expressly mentions gender equality as one of the SDGs. Discriminatory laws must be changed and legislation enacted to advance equality proactively to achieve the goals. Gender-based violence is a top priority for governments all across the world. India is dedicated to promoting equality for all of its residents. The Indian Constitution's Preamble, Fundamental Rights, and State Policy Directive Principles express a strong commitment to gender equality. Also, India is the signatory of UN Conventions like CEDAW, where its pledge towards gender justice is evident. Furthermore, India has incorporated various domestic laws in pursuance of its responsibility towards Gender Justice. However, in India, Discrimination against women remains a profound issue despite reforms in various laws and different policies. Several concerns like female labor force participation, crimes against women, education among women, and discrimination are evident. This paper mainly throws light on the status of Gender Justice in India. It will help the stakeholders working on SDGs and Gender justice in policy development. It will highlight the gains and gaps that India has so far accomplished and encountered.
\end{abstract}

Keywords: Sustainable Development Goals, UN, Women, India, Gender Justice, Gender Equality

\section{Introduction}

It is said that our wants are unlimited, but resources are limited. So, to pass on these resources to our future generations, the need of the hour is to adopt the sustainable 
development and growth process holistically. In 2015, a collection of seventeen interlinked goals were set up by the United Nations with an aim to achieve a sustainable prospect for all. These arewell known as sustainable development goals.

This paper revolves around a particular goal which is gender equality and is mentioned explicitly as Goal 5. Eradication of gender-based discrepancies is a key concern across the globe. India also has its promises and pledges towards achieving gender equality. Various reforms have been brought about in Indian laws, and several policies have been implemented to achieve equality among genders. Some of which are the domestic violence act 2005, Dowry Act, Sexual Harassment at Workplace Act 2012, and several schemes like "Beti Bachao Beti Padhao", "Single Girl Child Scholarship", "One Stop Centre", "Women Help Line", "UJJWALA", "Mahila Police Volunteers", "Nirbhaya" etc. However, discrimination based on gender remains a critical issue, which needs attention on a priority basis in India.

Sex ratio, the participation of the female labor force, crimes against women, education among women, and discrimination evident in the official data of the government agencies are some prime concerns prevalent in Indian society.

In India, almost half of the population is female. So, if the needs and interests of this section are overlooked, it will pose a massive hurdle in the overall development of the country. As Swami Vivekananda once said, "It is not possible for a bird to fly on one wing", the same is true for any nation's evolution. It is essential to acknowledge fundamental issues like the one of gender equality to grow wisely. Also, it is to be noted that when we say gender equality, it does not only mean equality for women. Instead, it is a term used comprehensively for all genders.

This paper attempts to study the SDGs and India's commitment to gender justice in-depth, covering an array of related subsections falling in this domain. This work will provide insights into what India has promised and what has been done on the ground level to achieve gender justice.

\section{Sustainable Development Goals (SDGs)}

Precursor of Sustainable Development Goals is Millenium Development Goals adopted in 2000 by the UN General Assembly. The United Nations General Assembly adopted Sustainable Development Goals in 2015 (Bexell \& Jönsson, 2017). All the UN member states endorsed it as a universal call to preserve the planet, secure all people have harmony, prosperity, and peace, and end poverty (Frey \& Sabbatino, 2018). These seventeen interconnected Goals are all integrated. The sanction that progress in one domain will affect others' results and growth must coordinate different social, economic, and environmental sustainability (Leal Filho et al., 2019). The countries pledged "Leave No One Behind" and committed to advance for those furthest behind first. SDGs are developed to bring positive changes in the world like eradicating poverty, zero discrimination against women, ending hunger, and soon(Mishra, 2019). Creativity, technology, and financial resources from society are necessary to achieve the same. (UNDP, n.d.-b) The United Nations has devised areas that 
states have to concentrate on while achieving gender equality. This target primarily encircles ending all forms of discrimination against women everywhere. Moreover, it targets eliminating violence against women in public and private areas, including trafficking, sexual and other forms of exploitation. Furthermore, it emphasizes eliminating all evil practices, such as child marriage, domestic violence, female genital mutilation, and so on(Milivojevic, Hedwards, \& Segrave, 2020). Lastly, the targets also focus on recognizing, valuing, and considering unpaid domestic work by providing public services, infrastructure, and social protection policies. In addition, it focuses on the promotion of shared responsibility within the household and the family to provide economic access to women (Razavi, 2016).

At the UN Conference on Sustainable Development, 2012 in Rio de Janerio, Sustainable Development Goals (SDGs) first came into being (Linnér \& Selin, 2013). The plan was to devise goals that meet the prominently facing economic, political and environmental challenges (Lélé, 1991). Therefore, the previously developed MDGs, developed in 2000, were replaced by the SDGs. Prior to it, MDGs for 15 years drove progress in some vital a reas like poverty, education, maternal health, water and sanitization, HIV/AIDS, and child mortality. MDGs gave that start that needed a finish that the SDGs gave to tackle the pressing challenges. The 17 interconnected Golas dealing with different aspects to achieve better climate, gender equality, eradicate poverty, economic prosperity was devised. It was introduced to improve the lives of future generations (Mensah, 2019). The SDGs are unique as they cover up issues concerning us. It underscores the international community's commitment to eradicating poverty once and for all. They are adamant that no one is left behind. More importantly, they include us all in creating a more sustainable, safer, and affluent world for all humanity (UNDP, n.d.-a).

\subsection{Agenda 2030}

Agenda 2030 is a plan of action to improve global peace via people, planet, and prosperity. SDGs came into being to counter the most significant global challenges. It was an immediate need for sustainable development (Nerini et al., 2018). Agenda 2030 is for all countries and stakeholders to act collaboratively to implement the 17 SDGs and 169 targets (Stafford-Smith et al., 2017). They endeavor to build on the MDGs and achieve what they were short of attaining (Alston, 2005). Agenda 2030 seeks to realize women's rights to achieve gender equality and the empowerment of all women. SDGs, together with targets, are integrated and indivisible. It balances the three dimensions of sustainable development: economic, environmental, and social (Gugunskiy, Chernykh, \& Khairutdinov, 2020).

It was a momentous decision on a broad, far-reaching, and people-centered set of universal and transformational Goals and targets (Behnassi et al., 2021). Agenda 2030 aims to end poverty and hunger globally, combat inequalities within countries, build peaceful, just, and inclusive societies, protect human rights and promote gender equality and women's empowerment by 2030. Moreover, it aims to ensure the long-term safety of the planet and its natural wealth (Zhang, Prouty, Zimmerman, \& Mihelcic, 2016). It fosters sustainable, inclusive, and long-term economic growth shared prosperity, and decent employment for all while considering diverse 
national development levels and capacities (Gupta \& Vegelin, 2016). It is recognized by all nations and applies to everyone, considering different national realities, capacities, levels of development, and national policies and goals. These are global goals and objectives that touch everyone on the planet, both developed and developing nations (Fukuda-Parr, 2014). They are indivisible and interconnected, and they balance the three elements of sustainable development. After two years of rigorous public deliberation and involvement with civil society and other stakeholders throughout the world, the goals and targets for combating the world's major crises have been established (Gugunskiy et al., 2020).

\subsection{Agenda 2030 on Gender Justice}

It is clear that enormous difficulties towards sustainable development exist. Inequalities within and across nations are becoming more visible in society. Massive differences in opportunity, income, and power continue to exist. Gender inequality continues to be a major issue. Gender equality and women's and girls' empowerment will help to achieve all of the Goals and goals. It is impossible to achieve full human potential and sustainable growth if half of the human race is denied human rights and opportunities. Equal access to excellent education, economic benefits, political involvement, and equal opportunities with men and boys for employment, leadership, and decision-making at all levels are critical to closing the gender gap.

If we work collectively, we can significantly increase investments to shrink the gender gap and boost support for institutions promoting gender equality and women's empowerment at the international and regional levels. All types of gender discrimination and violence against women shall be prohibited. The systematic mainstreaming of a gender viewpoint in Agenda implementation is essential (Gugunskiy et al., 2020).

Universal respect for human rights and dignity includes non-discrimination, the rule of law, equality, justice, respect for race, ethnicity, cultural diversity, and equal opportunity. (Addo, 2010) The world must invest in its children so that every child can grow up free of violence and exploitation. A prospect can be achieved in which all women and girls have complete gender equality, and all legal, social, and economic impediments to their empowerment have been removed. A just, egalitarian, tolerant, open, and socially inclusive world, with the most vulnerable needs, satisfied.

Goal 5 of the Sustainable Development Goals states that "Achieve gender equality and empower all women and girls" in it (Errami, Ochir, \& Peppoloni, 2021). There are several targets enshrined to achieve the required goals. They concern discrimination, violence, affirmative actions, women's participation, health issues, reproductive rights, enforcement of laws and policies, technological advancements, and many more strata to facilitate women's conditions to bring gender justice (Nhamo, Nhamo, \& Nhemachena, 2018).

The SDGs ' Agenda is to eliminate gender disparities in education and secure equal access to all education by 2030 (Boni, Lopez-Fogues, \& Walker, 2016). Appropriate policy frameworks must be developed at the national, regional, and international levels to attain the results. It must be centered on development policies that are pro-poor and gender-sensitive to strive towards gender equality and women's empowerment successfully. Furthermore, gender equality must 
be incorporated throughout all SDGs as Gender issues are prominent in all sustainable development efforts.

\subsection{Gender Indicators}

The SDGs come with their own indicators to help with the proper evaluation and development of the Goals. It is critical to increase responsibility for achieving the SDGs and ensuring gender equality and women's empowerment.

Gender equality indicators were created for the first time in 1995 at the Fourth World Conference on Women in Beijing (Odera \& Mulusa, 2020). The United Nations has defined 14 Indicators for SDG 5, i.e., Gender Equality (Eden \& Wagstaff, 2021). The indicators are the world's measurements for determining whether or not a goal has been fulfilled. Several indicators have been identified to achieve gender equality and reach the relevant objectives (Lee et al., 2016). From the presence of a legal framework for gender equality, the health status of women to economic, social, cultural participation, all the indicators are to measure how much gender equality has been achieved (Cornwall \& Rivas, 2015).

A controversy has erupted about the use of national vs. global metrics. Countries are misapplying the concept of "country ownership." They systematically substitute global SDG indicators with national proxy measures, making it impossible to assess global progress as a standard/common baseline. National indicators should supplement rather than replace global indicators that focus on the particular concerns of each country. Eurostat, CARICOM, the African Union, and the Pacific Community have developed regional "SDG indicator" frameworks that compete with, rather than complement, the global SDG indicator framework. The African Union's recent attempts to consolidate the various monitoring regimes are encouraging, but more needs to be done (Gennari, n.d.).

"Pietro Gennari, former Chief Statistician of the United Nations Food and Agriculture Organization (FAO), and Dorian Kalamvrezos Navarro, Programme Advisor in the Office of the Chief Statistician, FAO, have suggested that there is a need to rethink the existing paradigm of international statistical cooperation, which is driven by "twinning arrangements" in which a wealthy country provides direct technical assistance to a developing country or countries. In the past, such agreements may have been effective for transferring know-how in traditional data fields. They have doubtful relevance in international statistics since they are based on new common standards, techniques, and classifications that have yet to be embraced entirely even by advanced economies."

Indeed, the demise of international institutions has resulted in fragmented approaches that impede global SDG reporting. International organizations' capacity-building activities, for their part, may be considerably enhanced by increased coordination across agencies and more methodical follow-up by nations. We need to rethink the global partnership's goals for SDG data. They contended that piecemeal donor programs conducted by NGOs or non-state actors in the data realm result in a cacophony of varied tools and interfaces, frequently with the same or similar goals. Most typically, they are not linked to the national statistical system. To meet the demands of multiple players while retaining coherence and the engagement of official data producers, a more flexible but institutional approach is required. Without a doubt, this includes 
(C) Jameel \& Ahmed

the private sector. Private firms typically own alternative data sources, yet data-sharing standards are sometimes lacking. We must approach the simmering resentment and complex interconnections between the private sector and national statistics systems prudently rather than fanatically. If we adopt these steps, we should resurrect the data revolution and, more importantly, ensure that it evolves into a statistical revolution for the SDGs. Only then will we have a hope of resuming progress toward the 2030 Agenda (Gennari, n.d.).

\section{India's commitment}

Gender equality in India remains a contemporary issue that needs society, state, international and regional support. India is a country where women did not have to fight for voting rights though they have a hard fight for equality. Over the past two decades, India has shown improvement in improving standards of gender equality in the country. However, it remains unsatisfactory as the country still faces undeniable gender issues of inequality, misogyny, and sexism. In 2001 the government established a "National Policy for the Empowerment of Women", which drew momentary help(Dwivedi, 2015). There are better changes in reducing child marriages, increasing health standards, and reducing the number of girls' deaths through several schemes. However, among the 17 Sustainable Developmental Goals (SDGs) established by the United Nations (UN), SDG 5, which stands for gender equality, has proven to be the most difficult to campaign for and implement in India. According to the most recent SDG India Index Baseline Report (2018), all states - excluding Chandigarh, Sikkim, Kerala, and the Andaman \& Nicobar Islands - are in the red zone or "aspirant zone." The four states that are not in the red zone are in the "performer" zone, just above the aspirants (Aayog, 2018).

\subsection{India's policies vis a vis Gender Justice}

Women's empowerment has been identified as the fundamental problem defining women's position in recent years. Gender equality concepts are established in the Indian Constitution. The Constitution guarantees women's equality and authorizes the state to implement measures of positive discrimination in favor of women. Women's growth in many domains has been sought in India within the context of a democratic polity, laws, development policies, plans, and programs.

Fifth Five Year Plan (1974-78) onwards, a shift in women's issues from welfare to development has been adopted (Mokta, 2014). From the establishment of the National Commission for Women in 1990 to the 73rd and 74th Constitutional Amendments in 1993, which provided for the reservation of seats in Panchayats and Municipalities for women, a solid foundation was laid to protect women's rights and legal entitlements, as well as their participation in decisionmaking at the local level. Notwithstanding, there is still a wide gap between the goals enunciated in the Constitution, legislation, policies, plans, and programs (Pardhasaradhi \& Rao, 2014).

To ensure women's equal rights, India has ratified several international agreements and human rights instruments. The ratification of the Convention on the Elimination of All Forms of Discrimination Against Women (CEDAW) in 1993 is crucial (Holmes, 2019). The Nairobi 
Forward-Looking Strategies (1985), the Beijing Declaration as well as the Platform for Action (1995), Mexico Plan of Action (1975), and the Outcome Document adopted by the United Nations General Assembly Session on Gender Equality and Development and Peace for the Twenty-First Century, titled "Further actions and initiatives to implement the Beijing Declaration and the Platform for Action," are unequivocally validated by India for suitable development (Zinsser, 2002).

\subsection{Schemes for Economic Advancement of Women in India}

India has adopted several schemes for the economic advancement of women in India from time to time. It is to bring women into the economic sphere and inculcate a feeling of economic independence, eventually bringing them to par with men in Indian society. Such schemes for the upliftment of the status of women in India are enlisted below:

Table 1: Schemes for Economic Advancement of Women in India

\begin{tabular}{|c|c|c|}
\hline S.No. & Scheme/Program & Purpose \\
\hline 1. & Pradhan Mantri Jan Dhan Yojana & $\begin{array}{l}\text { To take new active measures for women's } \\
\text { equal access to economic resources, } \\
\text { ownership, control over property and land, } \\
\text { financial services, natural resources, and inheritance, } \\
\text { consistent with the law. }\end{array}$ \\
\hline 2. & $\begin{array}{l}\text { Deen Dayal Antyodaya Yojana } \\
\text { (DAY)- National Rural Livelihood } \\
\text { Mission (NRLM) }\end{array}$ & $\begin{array}{l}\text { To take new active measures for women's } \\
\text { equal access to economic resources, } \\
\text { ownership, control over property and land, } \\
\text { financial services, natural resources, and inheritance, } \\
\text { consistent with the law. }\end{array}$ \\
\hline 3. & $\begin{array}{l}\text { Deen Dayal Antyodaya Yojana (DAY) - } \\
\text { National Urban Livelihood Mission } \\
\text { (NULM) }\end{array}$ & $\begin{array}{l}\text { To take new active measures for women's } \\
\text { equal access to economic resources, } \\
\text { ownership, control over property and land, } \\
\text { financial services, natural resources, and inheritance, } \\
\text { consistent with the law. }\end{array}$ \\
\hline 4. & $\begin{array}{l}\text { Labour and Employment Statistical } \\
\text { System (LESS) }\end{array}$ & $\begin{array}{l}\text { To recognize and give value to 'unpaid care' and } \\
\text { 'domestic work' over the facility of the public service } \\
\text { area, infrastructure, and social-security plans. }\end{array}$ \\
\hline 5. & Pradhan Mantri Ujjwala Yojna & $\begin{array}{l}\text { to provide clean cooking fuel to every poor household, } \\
\text { especially in rural areas }\end{array}$ \\
\hline 6. & $\begin{array}{l}\text { Support to Training and Employment } \\
\text { Program (STEP) }\end{array}$ & $\begin{array}{l}\text { To give the opportunity } \\
\text { of employable skills to women and assist with } \\
\text { competencies so that they can grow into self-employed/ } \\
\text { entrepreneurs. }\end{array}$ \\
\hline 7. & $\begin{array}{l}\text { Rashtriya Gram Swaraj Abhiyan } \\
\text { (RGSA) }\end{array}$ & $\begin{array}{l}\text { Encourage women to participate in the } \\
\text { political, public, and economic life of the } \\
\text { country. The scheme ensures active } \\
\text { participation and makes accessible ways to women of } \\
\text { decision-making at all levels. }\end{array}$ \\
\hline
\end{tabular}

Source: NITI Ayog, File No.F-20019/PA-SDGs/2017-DMEO-Part (1) 


\subsection{Schemes for Health Development in India}

The importance of women's health is inevitable for their advancement in society. Without taking sufficient steps towards this aspect, women in India cannot realize economic, social, and political upliftment. The government has taken significant steps in this section, which are mentioned below:

Table 2: Schemes for Health Development in India

\begin{tabular}{|l|l|l|}
\hline S.No. & Scheme/Program & Purpose \\
\hline 1. & National AIDS Control Programme & It aims to prevent and control HIV/AIDS in India. \\
\hline 2. & $\begin{array}{l}\text { Pradhan Mantri Matru Vandana Yojana } \\
\text { (PMMVY) }\end{array}$ & $\begin{array}{l}\text { It aims to provide pregnant women with compensation } \\
\text { for the los of wages to take rest before and after } \\
\text { delivery of the first child. It foresees behind this purpose } \\
\text { to eradicate gender inequality. }\end{array}$ \\
\hline 3. & National Health Mission & $\begin{array}{l}\text { It envisions realizing collective access to affordable, } \\
\text { equitable, and quality amenities of health care. The } \\
\text { universal access to reproductive and sexual health, } \\
\text { reproductive rights of women, are the main focus of the } \\
\text { the scheme, also mentioned in International Conferences } \\
\text { such as the Beijing Platform of Action. }\end{array}$ \\
\hline
\end{tabular}

Source: NITI Ayog, File No.F-20019/PA-SDGs/2017-DMEO-Part (1)

\subsection{Schemes for Gender Equality of Women}

India has adopted several schemes from time to time for achieving Gender Equality. Apart from having several laws and constitutional frameworks to safeguard gender equality, a plan of action, policies, schemes, and government reforms are required. Moreover, monitoring the implementation of such strategies is needed to achieve the maximum outcome of the same.

Table 3: Schemes for Gender Equality of Women

\begin{tabular}{|c|c|c|c|}
\hline S.No & Name & Year & Purpose \\
\hline 1. & $\begin{array}{l}\text { Beti Bachao Beti Padhao } \\
\text { (BBBP) }\end{array}$ & 2015 & Address the declining Child Sex Ratio (CSR), other issues. \\
\hline 2. & $\begin{array}{l}\text { Pradhan } \\
\text { MantriMatruVandanaYojana } \\
\text { (PMMVY) }\end{array}$ & 2017 & $\begin{array}{l}\text { To contribute towards a better enabling environment by } \\
\text { providing cash incentives for improved health and } \\
\text { nutrition to pregnant and nursing mothers. }\end{array}$ \\
\hline 3. & $\begin{array}{l}\text { Adolescent Girls aims at girls } \\
\text { in the age group 11-14 }\end{array}$ & 2010 & $\begin{array}{l}\text { Empowerment and improvement of social status through } \\
\text { nutrition, life skills, home skills, and vocational training. }\end{array}$ \\
\hline 4. & $\begin{array}{l}\text { National Nutrition } \\
\text { Mission (NNM) }\end{array}$ & $2017-18$ & $\begin{array}{l}\text { To attain a "Suposhit Bharat", improving the nutritional } \\
\text { status of pregnant women and lactating mothers and } \\
\text { reducing anemia among women along with children. }\end{array}$ \\
\hline 5. & RastriyaMahilaKosh (RMK) & 1993 & $\begin{array}{l}\text { Extends micro-finance services to bring about socio- } \\
\text { economic upliftment of poor women. }\end{array}$ \\
\hline 6. & Mahila e-Haat & 1993 & $\begin{array}{l}\text { Direct online digital marketing platform for women } \\
\text { entrepreneurs/ SHGs/ NGOs. }\end{array}$ \\
\hline 7. & $\begin{array}{l}\text { Pradhan MantriMahila Shakti } \\
\text { Kendra }\end{array}$ & $2017-18$ & $\begin{array}{l}\text { Empowerment of rural women through community } \\
\text { participation }\end{array}$ \\
\hline 8. & $\begin{array}{l}\text { Training of Trainers of Elected } \\
\text { Women Representatives of } \\
\text { Panchayati Raj Institution }\end{array}$ & 2017 & To empower women and the functioning of PRIs. \\
\hline
\end{tabular}

Source: https://pib.gov.in/newsite/PrintRelease.aspx?relid=178437 


\subsection{Schemes/Programs for battling all forms of discrimination and violence against women in}

\section{India}

Violence against women and girls is prevalent in India. Different government reports are prooving the same. However, there are many laws for tackling this issue but failed to considerably bring down violence and discrimination against women. In order to support the laws, the government placed several programs and schemes for battling the same, which are as follows:

\section{Table 4: Schemes/Programs for battling all forms of discrimination and violence against} women in India

\begin{tabular}{|l|l|l|l|}
\hline S.No. & Scheme/Programme & Year & Purpose \\
\hline 1. & One-Stop Centres (OSCs)(Sakhi) & 2015 & $\begin{array}{l}\text { "Facilitation of services including police, medical, } \\
\text { legal, psychological support, and temporary shelter } \\
\text { to women affected by violence." }\end{array}$ \\
\hline 2. & Women Helpline & 2015 & $\begin{array}{l}\text { It provides women with a 24x7 service, Women } \\
\text { Helpline. It is an emergency response to women } \\
\text { affected by violence. }\end{array}$ \\
\hline 3. & Mahila Police Volunteers & $2016-17$ & $\begin{array}{l}\text { "A link between police and community that } \\
\text { facilitate women in distress." }\end{array}$ \\
\hline 4. & Swadhar Greh & 2015 & $\begin{array}{l}\text { It caters primary needs of women in difficult } \\
\text { circumstances. }\end{array}$ \\
\hline 5. & Ujjawala & 2016 & To prevent trafficking of women and children. \\
\hline
\end{tabular}

Source: https://archive.pib.gov.in/ndagov/Comprehensive-Materials/compr18.pdf

\subsection{Educational Provisions for Women and Girls}

There are rising worries about the consequences of the Gender Inclusion Fund for equal education for females and transgender pupils and a significant increase in public expenditure to raise education spending to $6 \%$ of GDP.

\section{Table 5: Educational Provisions for Women and Girls}

\begin{tabular}{|l|l|l|}
\hline S.No. & Scheme/Programme & Purpose \\
\hline 1. & Sukanya Samriddhi Yojna & $\begin{array}{l}\text { Girl children fund for future education and marriage } \\
\text { expenses. }\end{array}$ \\
\hline 2. & Balika Samridhi Yojna & $\begin{array}{l}\text { The scheme's major aims include promoting the enrolment } \\
\text { and retention of female children in schools and assisting in } \\
\text { raising girls until the legal age of marriage. If they are } \\
\text { successful, young girls will receive an education that will earn } \\
\text { a consistent wage. }\end{array}$ \\
\hline 3. & $\begin{array}{l}\text { CBSE Scholarship Scheme/Policy } \\
\text { for Girl Education }\end{array}$ & $\begin{array}{l}\text { It is available in India for one girl child per family and is } \\
\text { intended to complement the school tuition expense. }\end{array}$ \\
\hline
\end{tabular}

Source: https://transformingindia.mygov.in/scheme/sukanya-samriddhi-yojana/

\subsection{Scholarship schemes for higher education and research of girls}

Education is one of the most important spheres for the upliftment of society in general and women in particular. India's allocation of budget in higher education is significantly less. Women in higher education have seen a significant increase in India. It is all due to the 
government's effort to promote women in Higher education through scholarship schemes. These schemes help them support their education which was not previously the case. Some of the scholarship schemes with their purpose has been discussed below:

Table 6: Scholarship schemes for higher education and research of girls

\begin{tabular}{|l|l|l|}
\hline S.No. & Scheme & Purpose \\
\hline 1. & $\begin{array}{l}\text { PG Indira Gandhi Scholarship for } \\
\text { Single Girl Child }\end{array}$ & $\begin{array}{l}\text { To assist the Advancement of Girls participation in higher } \\
\text { education through scholarship }\end{array}$ \\
\hline 2. & $\begin{array}{l}\text { Swami Vivekananda Single Girl } \\
\text { Child Scholarship for Research in } \\
\text { Social Science. }\end{array}$ & $\begin{array}{l}\text { To assist the Advancement of Girls participation in Research } \\
\text { through scholarship. }\end{array}$ \\
\hline 3. & PRAGATI scholarship & $\begin{array}{l}\text { To assist the Advancement of Girls participation in Technical } \\
\text { Education through scholarships }\end{array}$ \\
\hline 4. & $\begin{array}{l}\text { Maulana Azad National } \\
\text { Fellowship }\end{array}$ & $\begin{array}{l}\text { It is a scholarship scheme where } 50 \text { percent of seats are } \\
\text { reserved for women candidates. }\end{array}$ \\
\hline
\end{tabular}

Source: https://www.thehindu.com/education/women-on-the-go/article26480439.ece

\subsection{Central Government Digital Programs and Initiatives for Promoting Girls' Education in India}

In the 21st century, ease of access to education through digital media is the reality. There are several government digital platforms where students can learn through digital reading materials and study new courses free of cost.

Table 7: Central Government Digital Programs and Initiatives for Promoting Girls' Education in India

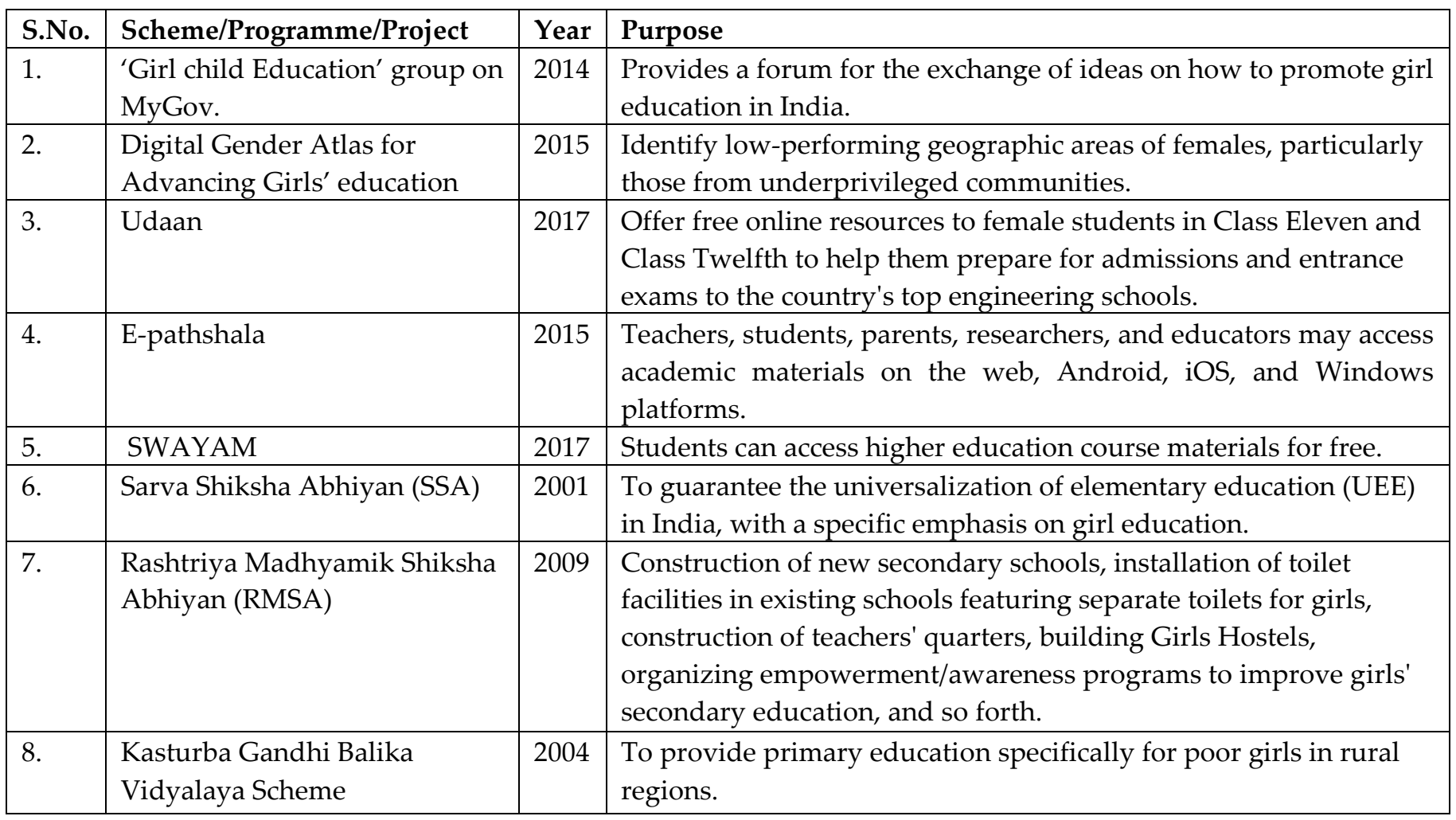

Source: https://www.digitalindia.gov.in/di-initiatives 
These initiatives have helped mainly women and girls, who at times, left behind due to traveling and dependence on male family members. Moreover, the government has taken significant steps to promote women and girls' education at the primary and secondary levels. Such schemes are elucidated in Table 7.

Aside from the national government, Indian state governments actively promote various programs that assist girls. While many of these programs focus on saving and education, others, such as the Kishori Shakti Yojana, try to educate teenage females on the need for health care. Adolescent females are given access to modern and up-to-date healthcare programs and instructions on proper cleanliness. Knowing about the 13 free life-saving vaccines provided by the government and the significance of MMR, Polio, and other equivalent immunizations is crucial for future mothers' health and reducing child mortality due to vaccine-preventable diseases.

\subsection{Schemes for Girls in India by different states}

India is the union of states with two governments, one at the union level and the other at the state level making it a federal form of government. Along with the policies and schemes of the union government, each state has its own government and policies for the welfare of its people. To promote women and girls in all spheres, the state governments too launched several schemes and programs to ameliorate the status of women in India. Some of the schemes for their promotion are listed in Table 8.

Table 8: Schemes for Girls in India by different states

\begin{tabular}{|l|l|c|}
\hline S.No & Scheme & State \\
\hline 1. & Rajshri Yojna & Rajasthan \\
\hline 2. & Bhagyalaxmi scheme & Karnataka \\
\hline 3. & Ladli Laxmi Yojana & Andhra Pradesh \\
\hline 4. & Girl child protection scheme & Chhattisgarh \\
\hline 5. & Saraswati Bicycle Scheme & Odisha \\
\hline 6. & Kishori Shakti Yojana & Bihar \\
\hline 7. & Mukhyamantri Kanya Suraksha Yojna & Uttar Pradesh \\
\hline 8. & Mukhyamantri Laadli Yojna & Delhi \& Haryana \\
\hline 9. & Ladli & Tamil Nadu. \\
\hline 10. & $\begin{array}{l}\text { Sivagami Ammaiyar Memorial girl child protection } \\
\text { scheme }\end{array}$ & Goa \\
\hline 11. & MAMTA scheme for girl child & . \\
\hline
\end{tabular}

Source: https://vikaspedia.in/social-welfare/women-and-child-development/child-development-1/girl-childwelfare/state-wise-schemes-for-girl-child-welfare

\section{Enrolment of girl students}

The government has introduced supernumerary seats in B.Tech programs at IITs to encourage female enrollment at the Indian Institutes of Technology (IITs). (Desk, 2019) Education for women is very significant as educating the girl means educating the family and eventually contributing to nation-building. "When you educate a man, you educate an individual, and when you educate a woman, you educate an entire family and subsequently the whole nation." 
(Herz, Herz, \& Sperling, 2004) This phrase has to be acknowledged by all the sections of society. India has so far committed to educating girls through several schemes.

Even after recognizing education as a basic right (Right to Education), the government has a number of problems in educating girls. One of the primary causes for this is the traditional attitude of families toward women and girls. Girls are still confined to domestic work in many areas of this country, particularly in rural areas (Raina \& Balodi, 2014).

\section{Gender Budgeting}

Gender budgeting is concerned with the gender-sensitive drafting of laws, programs, and schemes; allocation of resources; intended implementation and execution; audit and performance evaluation of programs and schemes; and trying to emulate corrective activities to recognize gender inequalities (Lahiri, Chakraborty, Bhattacharyya, Bhasin, \& Mukhopadhyay, 2002). It is a strong tool for accomplishing gender mainstreaming and ensuring that development gains are shared equally by men and women. It does not strive to create a distinct budget but instead seeks constructive action to meet the special needs of women. It examines spending and government service performance from a gendered perspective. It also demands an examination of the government finances to determine the gender differential repercussions and to guarantee that gender pledges are translated into fiscal commitments (O'Hagan, 2018).

The structure for Gender Budgeting can be described as:

Step 1: A review of the conditions for men and women (and the many sub-groups) in a certain subject.

Step 2: An assessment of how well the sector's system addresses the gender challenges and gaps identified in the first phase.

Step 3: Examine the appropriateness of budget resources for implementing the gendersensitive policies and initiatives identified in step 2.

Step 4: Check to see if the funds were spent as intended, what was given, and whom.

Step 5: Assess the policy/program/scheme's impact and the degree to which the circumstances described in step 1 have evolved.

Gender Budgeting is not a novel notion in Indian budgeting procedures. It was introduced in the 2001 Union Budget to address India's massive gender imbalance (Lahiri et al., 2002). Since 2005, the union government has issued the Gender Budgeting Statement consisting of two parts (Das \& Mishra, 2006):

- Part A reveals Women Specific Schemes.

- Part B reveals Pro Women Schemes.

India's gender budgeting challenges are notable across the world since they have affected expenditure and revenue strategies and have spread to state government levels. Gender budgeting in India is more than just an accounting chore. The gender budgeting system has aided gender-neutral ministries in developing new women's initiatives. Gender Budgeting Cells (GBC) are mandated as an institutional instrument for all Ministries/Departments. GBCs undertake gender-based influence analyses, beneficiary needs assessments, and beneficiary 
incidence analyses to identify opportunities for re-prioritizing public spending, enhancing implementation, and so on (Chakraborty, 2014).

All efforts toward development, poverty alleviation, and social indicator growth are fruitless unless policies, particularly for women and girls, are implemented. According to IMF research, over 16 Indian states have implemented gender-based budgeting, which is a significant accomplishment. Gender budgeting cells are developed inside each of the 56 federal ministries to define gender-related goals and strategies for achieving them. The Ministry of Women and Child Development has also created guidelines for incorporating gender budgeting into beneficiary-oriented initiatives (Chakraborty \& Singh, 2017).

However, there are specific special issues to consider when implementing gender budgeting. First, there is a lack of disaggregated gender-specific data for all schemes and initiatives under several ministries. Due to the scarcity of data, it is difficult to investigate the impact of financial allocations on gender equality. Second, the budgeting activity is concerned with strategies rather than results. Third, there is an urgent need to assess gender-specific factors and set targets accordingly. Fourth, the authority for providing responsibility to the process should be established. There is a need for potential development throughout government, public sector undertakings, non-governmental organizations (NGOs), corporations, and allied agencies. The distribution of responsibilities between the federal and state governments would aid in the process.

\section{Gaps and Challenges}

Gender inequality in India is a terrible issue, despite attaining high economic growth. Patriarchal customs and practices have been a reason behind them. Although there is an availability of a plethora of rights, programs, schemes for the welfare of women and girls to attain gender equality in a different section of the society, a need is required to look into the gaps that need to be addressed (Amit Kapoor, 2020). By monitoring and addressing the challenges in education, the participation of women in politics, a crime against women, and the participation of women in the workforce give a picture to tackle the issue of gender inequality. According to the Global Gender Index, India dropped four places from 2018 and ranked 112 (Nath \& Soni, 2021).

\subsection{Educational Attainment}

There are government schemes and programs to allow educating girls for higher literacy and enrolment rate of women in education, but still, gender inequality is evident. As per the World Economic Forums Global Gender Index 2019, India has slipped to $112^{\text {th }}$ place for educational attainment (Holmes, 2019). According to the Census 2011, the literacy rate among women was 65.46 percent; on the other hand, the literacy rate in men was 82.14 percent, making a malefemale literacy gap of 16.68 percent. In primary and tertiary education, the percentage of females attending school according to the 2011 census was not at par with the male population.

According to the latest All India Survey on Higher Education (AISH), male enrollment is 19.2 million, and female is 18.2 million. Male students proportion of enrollment in engineering and technology is $71.1 \%$ compared to female enrollment, which is low as $28.9 \%$. $(S, 2019)$ Much more 
has to be done to ensure that girls receive an education. It will need a far more effective implementation structure and a higher degree of broad public commitment. These efforts will fail to provide the intended results unless we raise public awareness about the benefits of women's education.

Women should be given equal opportunity as they are the foundation of a strong nation. Progress of any country requires the participation of women as they constitute half of their population. Consequently, to harness women's power for nation-building, we need to ensure that each child/woman can contribute and realize her full potential. Only then can we aim to claim our position amongst the league of superpowers of the world (Jain, 2019).

\subsection{Crime Against Women/Girls}

Crime against Women is on the increase every year. A jump of 7.3 percent of crime against women has been registered from 2018 to 2019 (NCRB, 2019). The total number of criminal cases against women reported under different heads of crimes was 405861 (NCRB, 2019). These cases include dowry, domestic violence, rape cases, registered under POSCO, and others. Child victims of rape were highest in the state of Rajasthan(1314), Andhra Pradesh(561), and Kerala(1271). Women victims of rape were around 25964 in Indian states. Rajasthan (18.24 percent) registered the highest number of rape victims. UP(11.01 percent), Madhya Pradesh(9.6 percent), Maharashtra(8.88 percent) were not much behind. Delhi constitutes 95 percent of registered cases of rapes amongst the UTs topped the list.

Uttar Pradesh has reported the highest number of cases of crime against women constituting 14.7 percent of the total cases in India. On the other hand, Assam registered the highest cases per lakh women population, comprising 177/lakh women. Being a national capital, Delhi is the highest amongst the UTs in Crime against women (NCRB, 2019).

This is not all. The sorry state of police can be seen through the government reports on the pending cases for investigation each year. The reported crimes, on the one hand, is on the increase. On the other hand, the number of pending cases each year is increasing too. As per the NCRB report, 185099 cases were pending investigation from the previous year before the police. This challenge has to be looked at seriously. Different states in India have the deteriorating condition of a slow investigation. Assam with 26663 pending cases was the highest on the list. With 24915 and UP with 17274 pending cases, Maharashtra needs to work efficiently in this section. Assam and Maharashtra have 80 percent or more of their police posts filled, but they are reporting 63 percent and 41 percent pendency cases, respectively. Uttar Pradesh has only 67 percent of its police force filled, and it reports only 19 percent pendency cases.

In contrast, with nearly the same proportion of sanctioned force filled, Tamil Nadu has double the pendency rate (39 percent). Kerala and Madhya Pradesh, with almost 80 percent of police sanctioned strength filled, have managed to bring down case pendency to 12 percent and 6 percent (Vedavalli \& Tvesha Sippy, 2019). Unoccupied police posts, inhumane work hours, lack of training are reasons why investigations of thousands of criminal cases are pending in India (Vedavalli \& Tvesha Sippy, 2019). A safe and secure environment is required for women to pursue their respective goals to make a mark in society. We have a lot of research showing the 
pending cases in the courts, but the NCRB data reveals another disturbing scenario. Therefore, it is not only the court lagging behind; it is also the police who cannot solve the criminal cases in time (Vedavalli \& Tvesha Sippy, 2019). To achieve gender equality, each target needs monitoring and reform.

\subsection{Political Empowerment of Women}

Women's representation in the political sphere is significant in empowering women and accomplishing gender equality. CEDAW advocates for women's rights in political life under Article 7 (Cho, 2014). It is one of the Indicator to calculate Gender Equality. Although India is still lagging behind many countries in women's political representation, it has improved this field. According to GGI 2020, the largest gender disparity has been observed in political empowerment. Women occupy only 25 percent of seats in the parliament around the world, and only 21 percent of them are ministers. India ranked $18^{\text {th }}$ among 153 countries in the political empowerment of women (Sharma, 2019). And, according to the Inter-Parliamentary Union, India ranked at $88^{\text {th }}$ in "Women in Politics Map 2017"(Union, 2017).

India paved the way for women's representation through reservation in the Panchayati Raj Institutions. Thirty-three percent were reserved for women candidates. However, this representation is not being seen at the national level in the form of reservation in parliament. Despite no reservation at the center, more women MPs are occupying seats in the parliament and state assemblies.

In the 2019 general elections, 78 women MPs out of 700 plus contested candidates were elected to the parliament. Although, women's participation and representation have increased from 4.4 percent at the time of the first Lok sabha to 14.36 in the seventeenth Lok Sabha, an increase of 10 percent. Still, when it comes to decision-making in politics, their number lies behind men. There are only 78 MPs out of the total number of 543 MPs in the LokSabha and 26 women MPs out of the 239 MPs in the Upper House of the parliament.

\subsection{Economic Participation and Opportunity}

In the economic upliftment of the country, gender parity is one of the essential elements. Women constitute half of the population of every nation. Without the participation of women, no economy can grow significantly. Besides, the participation of women in the economy is also crucial for the advancement of their position in society. In Indian society, what has been observed so far is that women contribute mainly as homemakers, upbringing their children, or work in family agriculture. Therefore, their participation in the economy is so marginal. And they are eventually leading to the deteriorating position of women in the country. Nevertheless, the government of India has significantly worked towards the increase in the participation of women in the economy. Several schemes, as discussed above, are efforts from the government. However, despite reaching the moon, India's reluctance to bring its women out of the house is concerning. The statistics in India's Economic Survey 2020 are startling. Housework is performed by around 60 percent of women in India between the ages of 15 and 59. Furthermore, the poll finds that female labor force participation fell to 25.3 percent in 2017-18, down from 33.1 
percent in 2011-12 ("Economic Survey 2020: 60\% Women in World's Fastest Growing Economy Do Housework," 2020).

Participation of women in the formal sector has been 24 percent, which has been constant in the last five years. It is anticipated that If women were represented in the formal economy at the same rate as men, the Indian economy might grow by $60 \%$ by 2025 , adding $\$ 2.9$ trillion to the GDP. ("Spotlight on India: Growing Economies Through Gender Parity," n.d.)

According to World Bank data issued in June 2020, India has the lowest female labor force participation (FLFP) in South Asia. Yemen, Iran, Jordan, Syria, Algeria, Iraq, the West Bank, and Gaza were the only nations that did worse. India's FLFP fell from 30.3 percent in 1990 to 20.3 percent in 2020, trailing Pakistan and Afghanistan at 22.2 percent and 21.8 percent, respectively. In 1990, the FLFP in Pakistan and Afghanistan stood at 14 percent and 15 percent, respectively. According to the Periodic Labour Force Survey (PLFS) data for 2017-18, seven percent in work participation rates (WPR) among rural women have been noticed, declining from 24.8 percent to 17.5 percent(Robertson, Lopez-Acevedo, \& Morales, 2020).

\subsection{Health and Survival}

Women's health is an essential factor that contributes to human wellbeing and economic growth. Health problem amongst women affects the aggregate economic output of India. Many factors affect women's health in India; maternal mortality is one. Maternal mortality is considered an essential health indicator. Maternal Mortality Ratio(MMR) of India for 2016-18, as per the latest report of the national Sample Registration System (SRS) data, is 113/100,000 live births, declining by 17 points, from 130/ 100,000 live births in 2014-16 (Goli, Puri, Salve, Pallikadavath, \& James, 2021). Female foeticide is another major problem in India. According to the United Nations, around 2,000 unborn girls are unlawfully terminated in India every day. This antifemale attitude, however, is not restricted to low-income households. A large part of the prejudice stems from cultural ideas and social standards. To achieve the needed aim of gender equality, these areas must be thoroughly examined.

\section{Conclusion}

The Agenda of Sustainable Development Goals supported the mainstream "Gender Equality and Women Empowerment." Women's empowerment is inextricably tied to the country's Sustainable Development target. A meaningful transition will not occur until the government increases its determination at all levels to disclose severe "gender inequities" and to make policy and implementation measures. As a notable signatory to Agenda 2030, India's government gradually develops efficient plans to meet the goals.

Significant progress has been accomplished in India over the previous decade in the form of legislation and policies aimed at improving the position of women. However, the growth is plodding due to the lack of adequate awareness of the national plans and programs for the eradication of Gender inequality from India. Indian women endured much degradation and faced a problematic level of deprivation in their families and society. Now the process of their emancipation through sustainable development has set an optimistic hope. To accomplish SDGs 
by 2030, women will surely get empowerment and equality in no small magnitude in India. A significant remark that amputation of poverty, more political and economic involvement of women, and universal access of primary and higher education and awareness programs for the effective implementation of national schemes will help achieve the Sustainable Development of women in India.

Furthermore, there is a need to significantly increase the budget allocation of gender-responsive schemes. Simply allocating funds will not be enough until there is a shift toward monitoring outcomes and effects on the ground rather than expenditure. Furthermore, intersectional policy research should help establish evidence-based gender policies to reduce gender inequities and contribute to overall development.

Authors' Contributions: Anas Jameel and Waseem Ahmed have their cumulative efforts to develop the idea, which is further realized through data collection. Moreover, Dr. Anas Jameel has analyzed the data and does the final compilation of the same.

Conflict of Interest: The authors declare no conflict of interest.

\section{REFERENCES}

Aayog, N. (2018). SDG India Index, Baseline Report, 2018. Government of India.

Addo, M. K. (2010). Practice of United Nations and Human Rights Treaty Bodies in the Reconciliation of Cultural Diversity with Universal Respect for Human Rights. Hum. Rts. Q., 32, 601.

Alston, P. (2005). Ships passing in the night: the current state of the human rights and development debate seen through the lens of the Millennium Development Goals. Human Rights Quarterly, 755-829.

Amit Kapoor. (2020, January 31). Budget 2020: The need for gender budgeting. Economic Times. Retrieved from https://economictimes.indiatimes.com/news/economy/policy/budget-2020-the-need-for-gender-

budgeting/articleshow/73793600.cms

Behnassi, M., Rahman, M. A., D'Silva, J., Ramachandran, G., Gupta, H., Pollmann, O., \& Ramachandran, N. (2021). Enhancing Resilience for Food and Nutrition Security Within a Changing Climate. In Emerging Challenges to Food Production and Security in Asia, Middle East, and Africa (pp. 1-42). Springer.

Bexell, M., \& Jönsson, K. (2017). Responsibility and the United Nations' sustainable development goals. Forum for Development Studies, 44(1), 13-29. Taylor \& Francis.

Boni, A., Lopez-Fogues, A., \& Walker, M. (2016). Higher education and the post-2015 agenda: A contribution from the human development approach. Journal of Global Ethics, 12(1), 17-28.

Chakraborty, L. (2014). Gender-responsive Budgeting as Fiscal Innovation: Evidence from India on'Processes'. Levy Economics Institute, Working Paper, (797).

Chakraborty, L., \& Singh, Y. (2017). Effectiveness of Gender Budgeting on Gender Equality and Fiscal Space: Empirical Evidence from Asia Pacific. Gender and Macroeconomics Conference.

Cho, S. (2014). International women's convention, democracy, and gender equality. Social Science Quarterly, 95(3), 719-739.

Cornwall, A., \& Rivas, A.-M. (2015). From 'gender equality and women's empowerment to global justice: reclaiming a transformative agenda for gender and development. Third World Quarterly, 36(2), 396-415.

Das, S., \& Mishra, Y. (2006). Gender budgeting statement: Misleading and patriarchal assumptions. Economic and Political Weekly, 41(30), 3285-3288.

Desk, I. T. W. (2019, June 28). Steps taken by government to increase enrolment of girls in higher studies. India Today. Retrieved from https://www.indiatoday.in/education-today/news/story/steps-taken-by-government-toincrease-enrolment-of-girls-in-higher-studies-1557947-2019-06-28

Dwivedi, V. (2015). Women empowerment in India. The Social ION, 4(1and2), 166-170.

84 Published by Research E Innovation Initiative, 3112 Jarvis Ave, Warren, MI 48091, USA 
(C) Jameel \& Ahmed

Economic Survey 2020: 60\% Women in World's Fastest Growing Economy Do Housework. (2020). Retrieved February 14, 2021, from Business Today website: https://www.businesstoday.in/current/economypolitics/economic-survey-2020-60-percent-women-in-the-world-fastest-growing-economy-do-onlyhousework/story/395111.html.

Eden, L., \& Wagstaff, M. F. (2021). Evidence-based policymaking and the wicked problem of SDG 5 Gender Equality. Journal of International Business Policy, 4(1), 28-57.

Errami, E., Ochir, G., \& Peppoloni, S. (2021). Achieve Gender Equality and Empower All Women and Girls. In J. C. Gill \& M. Smith (Eds.), Geosciences and the Sustainable Development Goals (1st ed., pp. 105-126). Springer. https://doi.org/10.1007/978-3-030-38815-7_5

Frey, M., \& Sabbatino, A. (2018). The role of the private sector in global sustainable development: The UN 2030 agenda. In Corporate responsibility and digital communities (pp. 187-204). Springer.

Fukuda-Parr, S. (2014). Global goals as a policy tool: intended and unintended consequences. Journal of Human Development and Capabilities, 15(2-3), 118-131.

Gennari, P. (n.d.). Are We Serious About Achieving the SDGs? A Statistician's Perspective. Retrieved January 11, 2021, from https://sdg.iisd.org/commentary/guest-articles/are-we-serious-about-achieving-the-sdgs-astatisticians-perspective/

Goli, S., Puri, P., Salve, P., Pallikadavath, S., \& James, K. S. (2021). Estimates and Correlates of District-Level Maternal Mortality Ratio in India. MedRxiv.

Gugunskiy, D., Chernykh, I., \& Khairutdinov, A. (2020). Legal models for activities on the exploration and utilization of space resources: towards the "space-2030" agenda. 13th International Scientific and Practical Conference-Artificial Intelligence Anthropogenic Nature Vs. Social Origin, 657-664. Springer.

Gupta, J., \& Vegelin, C. (2016). Sustainable development goals and inclusive development. International Environmental Agreements: Politics, Law and Economics, 16(3), 433-448.

Herz, B., Herz, B. K., \& Sperling, G. B. (2004). What works in girls' education: Evidence and policies from the developing world. Council on foreign relations.

Holmes, C. E. (2019). Conventions, courts, and communities: gender equity, CEDAW and religious personal law in India. Journal of Asian and African Studies, 54(7), 965-979.

Jain, R. (2019). Best Digital Initiatives For Promoting Girl Education In India. Retrieved January 11, 2021, from ASMA website: https://www.asmaindia.in/blog/best-digital-initiatives-for-promoting-girl-education-in-india/

Lahiri, A., Chakraborty, L., Bhattacharyya, P. N., Bhasin, A., \& Mukhopadhyay, H. (2002). Gender budgeting in India. UNIFEM, South Asia and Ministry of Human Resource Development, Government of India, New Delhi.

Leal Filho, W., Tripathi, S. K., Andrade Guerra, J., Giné-Garriga, R., Orlovic Lovren, V., \& Willats, J. (2019). Using the sustainable development goals towards a better understanding of sustainability challenges. International Journal of Sustainable Development \& World Ecology, 26(2), 179-190.

Lee, B. X., Kjaerulf, F., Turner, S., Cohen, L., Donnelly, P. D., Muggah, R., ... MacGregor, L. S. (2016). Transforming our world: implementing the 2030 agenda through sustainable development goal indicators. Journal of Public Health Policy, 37(1), 13-31.

Lélé, S. M. (1991). Sustainable development: a critical review. World Development, 19(6), 607-621.

Linnér, B.-O., \& Selin, H. (2013). The United Nations Conference on Sustainable Development: forty years in the making. Environment and Planning C: Government and Policy, 31(6), 971-987.

Mensah, J. (2019). Sustainable development: Meaning, history, principles, pillars, and implications for human action: Literature review. Cogent Social Sciences, 5(1), 1653531.

Milivojevic, S., Hedwards, B., \& Segrave, M. (2020). Examining the promise and delivery of Sustainable Development Goals in addressing human trafficking and modern slavery. In The Emerald Handbook of Crime, Justice and Sustainable Development. Emerald Publishing Limited.

Mishra, V. (2019). 'Leave no one behind'1: South Asian perspectives on achieving gender equality. In Social Development and the Sustainable Development Goals in South Asia (pp. 111-127). Routledge.

Mokta, M. (2014). Empowerment of women in India: A Critical Analysis. Indian Journal of Public Administration, 60(3), 473-488. 
Nath, P. R., \& Soni, C. (2021). Women and Work in Post-reform India. Understanding Vulnerabilities in Contemporary Society: Psychological Insights and Reflections, 179.

NCRB. (2019). NCRB Report. Retrieved from https://ncrb.gov.in/sites/default/files/CII 2019 Volume 1.pdf

Nerini, F. F., Tomei, J., To, L. S., Bisaga, I., Parikh, P., Black, M., ... Anandarajah, G. (2018). Mapping synergies and trade-offs between energy and the Sustainable Development Goals. Nature Energy, 3(1), 10-15.

Nhamo, G., Nhamo, S., \& Nhemachena, C. (2018). What gets measured gets done! Towards an Afro-barometer for tracking progress in achieving Sustainable Development Goal 5. Agenda, 32(1), 60-75.

O'Hagan, A. (2018). Conceptual and institutional origins of gender budgeting. In Gender budgeting in Europe (pp. 19-42). Springer.

Odera, J. A., \& Mulusa, J. (2020). SDGs, Gender Equality and Women's Empowerment: What Prospects for Delivery? In M. Kaltenborn, M. Krajewski, \& H. Kuhn (Eds.), Sustainable Development Goals and Human Rights (pp. 95-118). Cham: Springer International Publishing.

Pardhasaradhi, Y., \& Rao, V. N. (2014). Women Empowerment: Information Technology As A Critical Input. Indian Journal Of Public Administration, 60(3), 515-526.

Raina, D., \& Balodi, G. (2014). Menstrual hygiene: knowledge, practice, and restrictions amongst girls of Dehradun, Uttarakhand, India. Global Journal of Interdisciplinary Social Sciences, 3(4), 156-162.

Razavi, S. (2016). The 2030 Agenda: challenges of implementation to attain gender equality and women's rights. Gender \& Development, 24(1), 25-41.

Robertson, R., Lopez-Acevedo, G., \& Morales, M. (2020). The Relationship between Female Labor Force Participation and Violent Conflicts in South Asia. World Bank Policy Research Working Paper, (9195).

S, S. K. (2019, September 23). Big Drop In Students Entering Engineering, Arts Courses. NDTV. Retrieved from https://www.ndtv.com/education/aishe-2018-19-report-big-fall-in-students-entering-engineering-arts-courses2105733

Sharma, N. C. (2019, December 17). India Slips Four Ranks on World Economic Forum's Global Gender Gap Index 2020. Livemint. Retrieved from https://www.livemint.com/news/india/india-slips-four-ranks-on-worldeconomic-forum-s-global-gender-gap-index-2020-11576574974188.html.

Spotlight on India: Growing Economies Through Gender Parity. (n.d.). Retrieved from Council on Foreign Relations website: https://www.cfr.org/womens-participation-in-global-economy/

Stafford-Smith, M., Griggs, D., Gaffney, O., Ullah, F., Reyers, B., Kanie, N., ... O'Connell, D. (2017). Integration: the key to implementing the Sustainable Development Goals. Sustainability Science, 12(6), 911-919.

UNDPa. (n.d.). Background of the Sustainable Development Goals. Retrieved January 11, 2021, from UNDP website: https://www.undp.org/content/undp/en/home/sustainable-development-goals/background/

UNDPb. (n.d.). What are the Sustainable Development Goals? Retrieved January 11, 2021, from UNDP website: https://www.undp.org/content/undp/en/home/sustainable-development-goals.html

Union, I. P. (2017). Women in politics: 2017. Map. United Nations Entity for Gender Equality and the Empowerment of Women. Https://Www. Ipu. Org/Resources/Publications/Infographics/2017-03/Women-in-Politics-2017 (April 27, 2019).

Vedavalli, P., \& Tvesha Sippy. (2019, December 20). Don't just blame India's courts, it's the police that can't solve criminal cases in time. The Print. Retrieved from https://theprint.in/opinion/dont-just-blame-indias-courts-itsthe-police-that-cant-solve-criminal-cases-in-time/337951/

Zhang, Q., Prouty, C., Zimmerman, J. B., \& Mihelcic, J. R. (2016). More than target 6.3: a systems approach to rethinking sustainable development goals in a resource-scarce world. Engineering, 2(4), 481-489.

Zinsser, J. P. (2002). From Mexico to Copenhagen to Nairobi: The United Nations Decade for Women, 1975-1985. Journal of World History, 139-168. Retrieved from https://www.jstor.org/stable/20078945.

(C) 2021 by the authors. Licensee Research $\mathcal{E}$ Innovation Initiative, Michigan, USA. This article is an open-access article distributed under the terms and conditions of the Creative Commons Attribution (CC-BY) license (http://creativecommons.org/licenses/by/4.0/). 